\title{
Research on Exhaust Gas Cleaning System (EGCS) used in shipping industry for reducing $S O_{x}$ emissions
}

\author{
Mihail-Vlad Vasilescu ${ }^{1}$, Dumitru Dinu ${ }^{1}$, Mariana Panaitescu ${ }^{2, *}$ and Fanel-Viorel \\ Panaitescu $^{2}$ \\ ${ }^{1}$ Constanta Maritime University, Doctoral School of Mechanical Engineering, 104 Mircea cel Batran \\ Street, 900663 Constanta, Romania \\ ${ }^{2}$ Constanta Maritime University, Faculty of Electromechanics, 104 Mircea cel Batran Street, 900663 \\ Constanta, Romania
}

\begin{abstract}
Nowadays maritime transportation develops environmental pollution issues. On 1st of January 2020 "International Maritime Organization (IMO)" give a new amendment which limits the sulphur content in the fuel oil used on board ships operating outside designated emissions control area (ECA) to $0.50 \% \mathrm{~m} / \mathrm{m}-$ a significant reduction from previous limit of $3.5 \%$. In ECA the sulphur content in the fuel must be maximum $0.10 \% \mathrm{~m} / \mathrm{m}$. In order to comply with the new regulation maritime industry has to search for new methods of reducing the $\mathrm{SO}_{\mathrm{x}}$ emissions. This article major points are: environmental pollution due to maritime transportation nowadays; methods for shipping industry to comply with IMO 2020 amendment; the use of an EGCS (Exhaust Gas Cleaning System) in order to reduce the output of $\mathrm{SO}_{X}$; discharge washwater chemistry; titration curve and dilution requirement; use CFD modeling in order to determine the expected flow and mixing profiles for the discharge washwater of an acidic effluent waste stream from ship into the ocean; comparison between the manufacturer system specification and the CFD modeling results; conclusions.
\end{abstract}

\section{Introduction}

\subsection{Environmental pollution due to maritime transportation nowadays}

In the last 30 years the chemical structure of the atmosphere has change due to polluting emissions of different gases and PM which destroy the ozone layer. [1]

For this reason, IMO on 1st of January 2020 give a new amendment which limits the sulphur content in the fuel oil used on board ships operating outside designated emissions control area (ECA) to $0.50 \% \mathrm{~m} / \mathrm{m}$ - a significant reduction from previous limit of $3.5 \%$. In ECA the sulphur content in the fuel must be maximum $0.10 \% \mathrm{~m} / \mathrm{m}$. In order to comply with

\footnotetext{
*Corresponding author: panaitescumariana1@gmail.com
} 
the new regulation maritime industry has to search for new methods of reducing the $\mathrm{SO}_{\mathrm{x}}$ emissions.

\subsection{Methods for shipping industry to comply with IMO 2020 amendment}

In order to comply with the new rule, the shipping industry has a few options:

- the first alternative could be to use a compliant fuel with lower sulphur content, an alternative fuel like LNG or methanol;

- a second alternative could be to install a green energy source like: Flettner Balloon with Helium, Vertical wind turbines, Solar panels, Kites; these alternative solutions are used for reducing the fuel oil consumption of the electric generators in the ship power plant (not for propulsion);

- the third alternative could be to clean its exhaust gases with a "scrubber" technology to reduce the output of $\mathrm{SO}_{x}$.

\subsection{The use of an Exhaust Gas Cleaning System in order to reduce the output of $\mathrm{SO}_{\mathrm{x}}$}

\subsubsection{System description}

The Exhaust Gas Cleaning System (EGCS) is based on the principle of scrubbing. The EGCS is composed of one Exhaust Gas Cleaning (EGC) unit, appointed scrubber (Figure 1)[2], exhaust gas supplying and discharging system and seawater supplying and washwater discharging system. The EGC unit is designed to be continuously operated in a wet (scrubbing) condition. The EGC unit is designed to pre-treat the exhaust gas and intimately mix the gas with seawater to remove $\mathrm{SO}_{\mathrm{x}}$ and particulate matter emissions generated from burned fuel.

Exhaust gas pipes are conducted to the EGC unit (Figure 2). Continuous Emissions Monitoring System (CEMS) is equipped in the gas outlet duct of the EGC unit to monitor $\mathrm{CO}_{2}$ and $\mathrm{SO}_{2}$ in exhaust gas.

Scrubber water monitoring sensor is also installed in the washwater discharging pipe for sensing polycyclic aromatic hydrocarbons (PAHs), $\mathrm{pH}$, temperature and turbidity.

In the open loop mode, the scrubber water is supplied from the sea chest and pumped to the EGC unit, where the water is sprayed in two stages. The first stage is in the bottom spray at EGC body, in order to improve gas flow, reduce back pressure and catch particulate matter and sulphur. The second stage is in the top of the EGC body. Internal mist eliminator at the next of top spray effectively prevents water droplets to be carried away with the outlet gas flow. A bypass arrangement is needed and is permitting operation of the combustion units. In the open loop mode, the washwater is drained from the EGC unit and discharged overboard. 


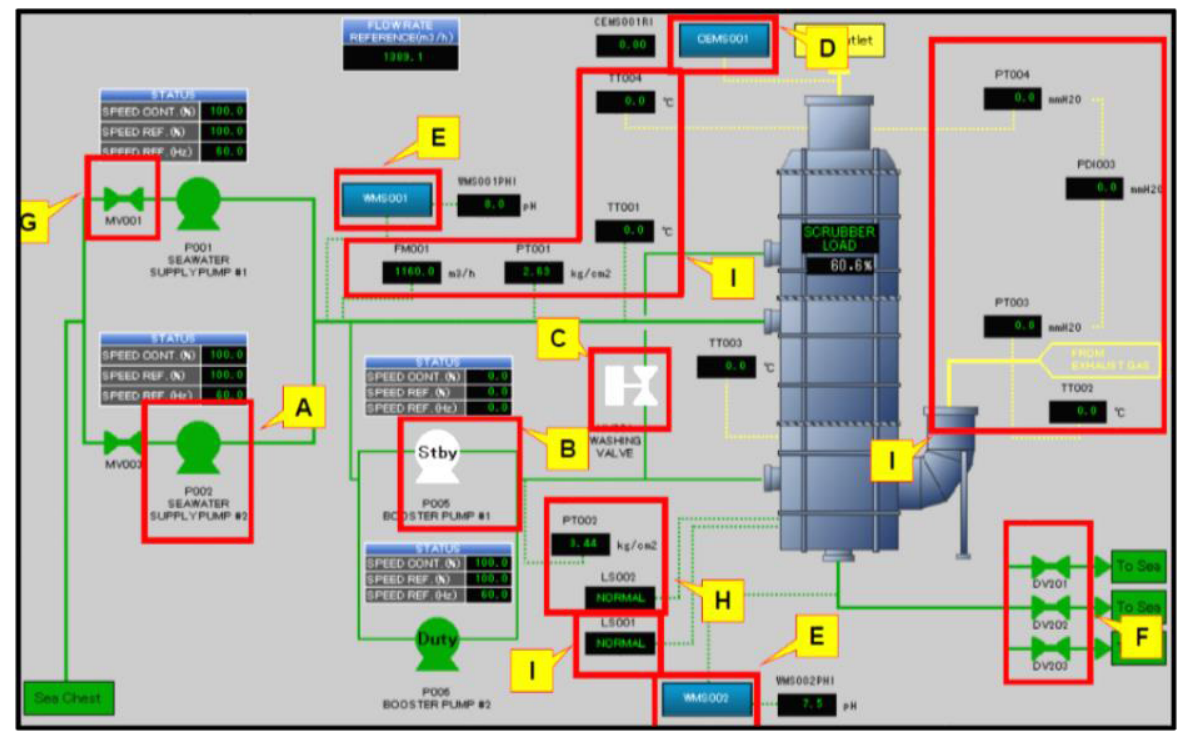

Fig. 1. Exhaust Gas Cleaning System -Scrubber

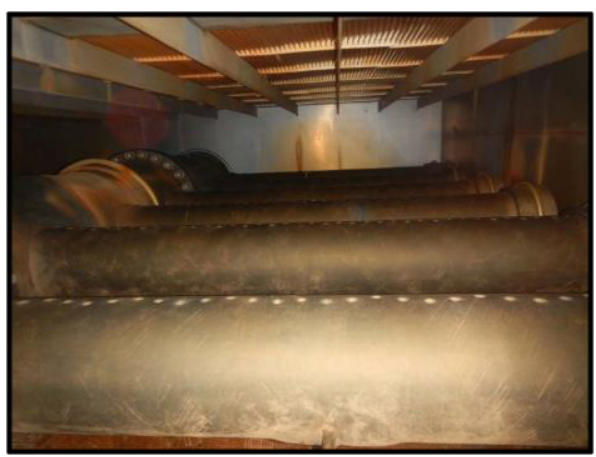

Fig. 2. Exhaust gas pipes

In the Figure 1:

- A is the seawater supply pump is to provide water from sea chest to scrubber.

- $\mathrm{B}$ are the booster pumps will serve as making the hot exhaust gas cool and washing the mist eliminator by the seawater sprayed on scrubber.

- $\mathrm{C}$ is the washing valve which provide seawater to wash the mist eliminator by washing water.

- $\mathrm{D}$ is the Control Environment Systems (CEMS) which can measure sulfur dioxide, carbon monoxide, ratio $\mathrm{SO} 2 / \mathrm{CO} 2, \mathrm{H} 2 \mathrm{O}$.

- $\mathrm{E}$ is the Water Measurement Systems (WMS) which can measure PAHs, turbidity, $\mathrm{pH}$, temperature.

- $\quad \mathrm{F}$ is the overboard valve which is used for discharging the seawater after scrubbing with the gas.

- $\mathrm{G}$ is the suction valve which is used to indicate inlet valve status, if this valve is closed, seawater supply pump must be stopped. 
- $\quad \mathrm{H}$ is the level switch which is used to detect the water which is flowing into the scrubber body. When LS002 alarm occurs, the system should shut down to protect the water flowing into the $\mathrm{M} / \mathrm{E}, \mathrm{G} / \mathrm{E}$, Auxiliar Boiler.

- $\quad \mathrm{I}$ is the measuring equipment:

FM001: Seawater supply flow (Figure 3);

TT001: Seawater supply temperature;

TT002: Inlet exhaust gas temperature;

TT003: Packing inlet temperature;

TT004: Outlet exhaust gas temperature;

PT001: Seawater supply pressure;

PT002: Booster pump pressure (Figure 4);

PT003 \& PT004: Scrubber differential pressure.

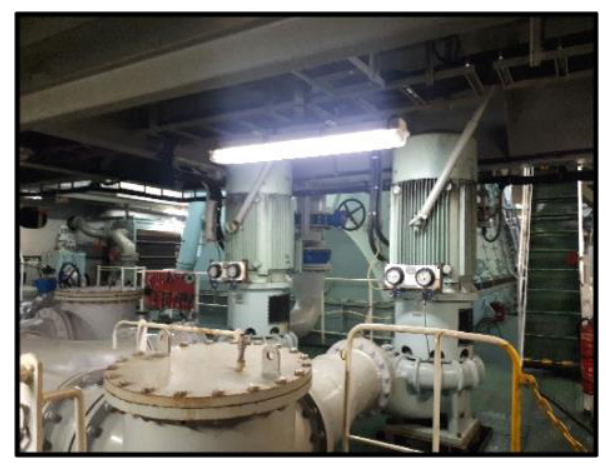

Fig. 3. Seawater supply pumps

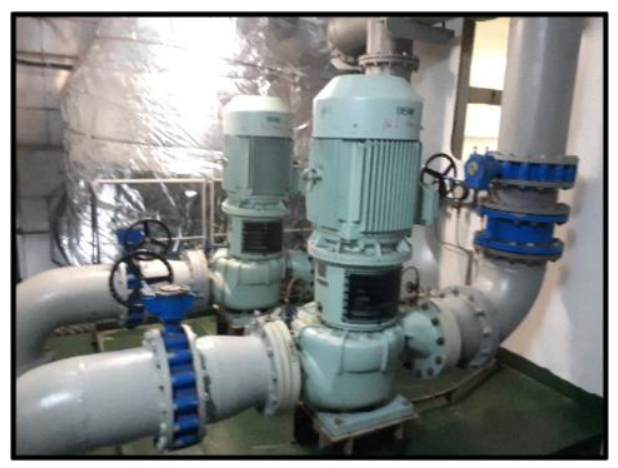

Fig. 4. Booster pumps

The ECGS [3] is shows in the Figure 3: 


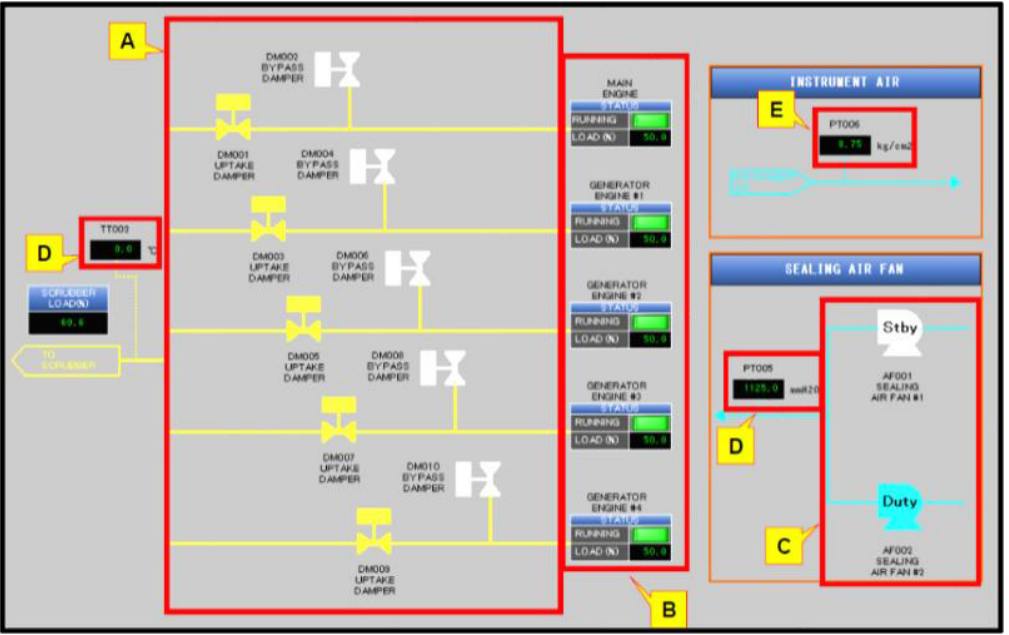

Fig. 5. Exhaust Gas Cleaning System

where:

- $\mathrm{A}$ is the uptake and bypass dampers which are used to lead the exhaust gas in the desired direction. When the scrubber is in operation, the exhaust gas is led from the engine or generator through the respective uptake damper to the scrubber.

- B indicates the information received from alarm monitoring system and affect the uptake \& bypass damper control. Indicates the main engine, generators: 1, 2, 3, 4, Auxiliar Boiler run \& load status which are received from alarm monitoring system.

- $\quad \mathrm{C}$ is the sealing air fan which provides the sealing air necessary to close the valve of uptake and bypass dampers and prevent gas flowing into residential areas.

- $\quad \mathrm{D}$ is the measuring equipment:

PT005: Sealing air fan pressure;

TT002: Inlet exhaust gas temperature;

- $\quad \mathrm{E}$ is the instrument air

PT006: Instrument Air Pressure.

\subsubsection{System performance}

The EGCS is designed to reduce $\mathrm{SO}_{\mathrm{x}}$ emissions to a level not exceeding an equivalent of $0.5 \% \mathrm{~m} / \mathrm{m}$ sulphur content in the fuel $\left(\mathrm{SO}_{2} / \mathrm{CO}_{2}\right.$ ratio of 21.7 or less) for global and/ or 0.10 $\% \mathrm{~m} / \mathrm{m}$ sulphur content in the fuel $\left(\mathrm{SO}_{2} / \mathrm{CO}_{2}\right.$ ratio of 4.3 or less), when the combustion units are operated on a fuel that contains a maximum of $3.5 \% \mathrm{~m} / \mathrm{m}$ sulphur. [4]

Table 1. Typical $\mathrm{SO}_{2} / \mathrm{CO}_{2}$ ratios based on fuel sulphur content

\begin{tabular}{|c|c|}
\hline $\begin{array}{c}\text { FO Sulphur content }(\% \\
\mathrm{m} / \mathrm{m})\end{array}$ & $\begin{array}{c}\text { Ratio emissions SO2 } \mathrm{ppm} / \mathrm{CO} 2 \\
(\% \mathrm{v} / \mathrm{v})\end{array}$ \\
\hline 0.50 & 21.7 \\
\hline 0.10 & 4.3 \\
\hline
\end{tabular}




\subsubsection{System configuration}

In the open loop mode, exhaust gas is fed the scrubber body via scrubber inlet manifold pipe. Manifold pipe is sized to optimize the flow uniformity in the scrubber. Exhaust gas passes through the packing material for ensures good contact between exhaust gas and liquid resulting in a highly efficient $\mathrm{SO} 2$ absorption. The treated flue gas from the scrubber is routed to the atmosphere through the stack. Fresh seawater is used for removal of $\mathrm{SO}_{\mathrm{x}}$. Seawater is routed from the sea chest to the seawater supply pumps and then divided into the scrubber and booster pumps. The water that goes to the scrubber body directly is used for the scrubbing water. For the scrubbing spray, HPS (Hyundai Power Systems) scrubbing system adopted nozzle-free spray system which lead lower electric power than the nozzle spray system (Figure 6) [5].

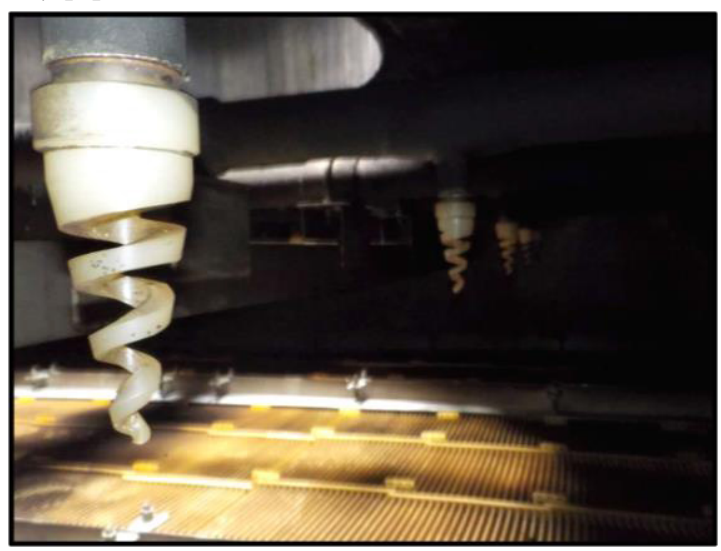

Fig.6. Nozzle spray system

The other water is pumped by booster pump, in order to have enough pressure for quenching spray and mist eliminator washing water. All used seawater is routed to the sea through the overboard valve.

\section{Methods and researches}

\subsection{Discharge washwater chemistry}

The $\mathrm{SO}_{\mathrm{x}}$ in the exhaust gas is present mainly as $\mathrm{SO}_{2}$, which in seawater is hydrated to $\mathrm{H}_{2} \mathrm{SO}_{3}$. The more $\mathrm{SO}_{2}$ that is dissolved in the washwater, the lower $\mathrm{pH}$ value will be in the discharged water (Figure 7)[6]. The washwater in an EGCS is never exposed to atmospheric conditions after absorbing the $\mathrm{SO}_{2}$. It is kept in closed tanks, scrubbers and pipes prior to release. It is thus important to include in the chemical model such conditions. After discharge of the washwater into the ocean, the mixing with pure seawater will cause the $\mathrm{pH}$ to increase. The $\mathrm{pH}$ increase is due to both a dilution effect and a further neutralization caused by the alkalinity in the seawater. The major contributor to the alkalinity in seawater is carbonate and bicarbonate, and the neutralization process leads to release of $\mathrm{CO}_{2}$. The rate of stripping of $\mathrm{CO}_{2}$ from the seawater is thereby a limiting factor for the $\mathrm{pH}$-recovery, and less $\mathrm{CO}_{2}$ stripping means that the dilution has to be increased. 


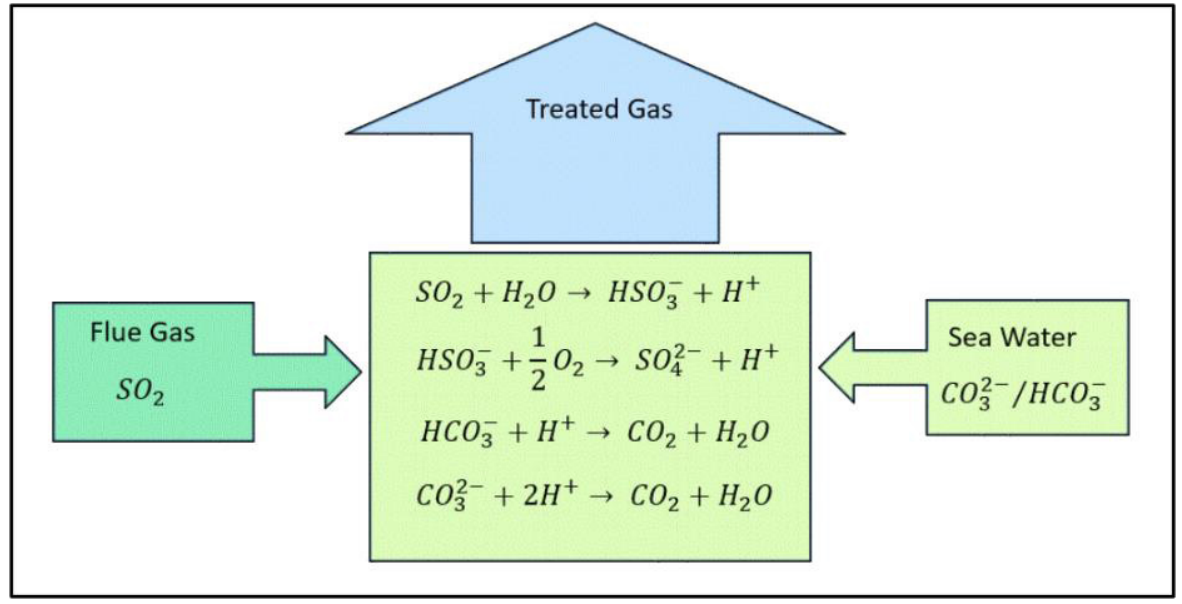

Fig. 7. Chemistry for $\mathrm{SO}_{2}$ removal by seawater.

Figure 7 shows the chemical process in which $\mathrm{SO}_{2}^{-2}$ generated after $\mathrm{SO}_{2}$ is absorbed in seawater, is neutralized by carbonate, $\mathrm{CO}_{3}^{-2}$, and bicarbonate, $\mathrm{HCO}_{3}{ }^{-}$, the base compounds in seawater.

\subsection{Titration Curve and Dilution Requirement}

The Titration curve is prepared by using a chemical equilibrium model for seawater [6]. The model includes inorganic carbon, boric acid, sulfate, fluoride and dissolved $\mathrm{SO}_{2}$ equilibrums, the equilibrium constants are function of salinity (ionic strength) and temperature.

Basis for the calculation:

- released $\mathrm{CO}_{2}$ retained in solution, i.e no forced stripping of $\mathrm{CO}_{2}$;

- $10 \%$ of dissolved S (IV) oxidized to S (Vl) inside scrubber system;

- $\quad$ seawater alkalinity $2.2 \mathrm{mml} / \mathrm{l}$;

- $\quad$ seawater salinity $35 \mathrm{psu}$;

- $\quad$ seawater $\mathrm{pH} 8.2$;

- seawater temperature $32^{\circ} \mathrm{C}$ (for the 0 class ships, we take always the worst condition for seawater temperature).

The fit equation is provided based on an empirical equation fit to the curve. The equation is:

$p H=3.84-0.2308 \times \mathrm{SO}_{2}+\frac{1.403}{\left(0.0403+\exp \left(2.966 \times\left(\mathrm{SO}_{2}-0.189\right)\right)\right)}+\frac{9.947}{\left(4.605+\exp \left(4.554 \times\left(\mathrm{SO}_{2}-1.588\right)\right)\right)}$

Where the variable $\mathrm{SO}_{2}$ absorbed in mmole/kg seawater. The "fit equation" is used for the determination of the dilution factor.

The seawater with dilution ratio, 1.6:8.4 (16\%) is required to reach $\mathrm{pH} 6.5(0.46 \mathrm{mmol}$ $\mathrm{SO}_{\mathrm{x}} / \mathrm{kg}$ ) when the $\mathrm{pH}$ of discharge washwater is 3.2. (3.9 mmol $\mathrm{SO}_{\mathrm{x}} / \mathrm{kg}$ ). As can be seen from titration curve, lower dilution rate is required to reach the $\mathrm{pH} 6.5$ before $4 \mathrm{~m}$ from discharge point if the $\mathrm{pH}$ of discharge washwater is more than 3.2. 


$$
\begin{aligned}
& \text { Dilution factor }=\frac{2.89}{0.46}=6.23 \\
& \text { Dilution ratio }=\frac{1}{6.23} \times 100=16 \%
\end{aligned}
$$

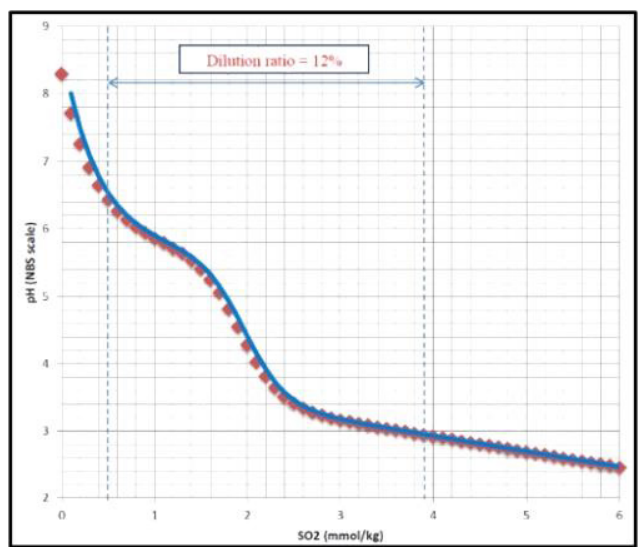

Fig. 8. Titration Curve.

\subsection{Use CFD modeling in order to determine the expected flow and mixing profiles for the discharge washwater of an acidic effluent waste stream from ship into the ocean}

\subsubsection{CFD Model Geometry}

The current CFD analysis was conducted on the basis of hull section information and considered discharge nozzle's location \& light draft [6]. Especially, this analysis focused on $4 \mathrm{~m}$ distance from discharge nozzle.

Model geometry with 3 discharge nozzles was used with this vessel. Three $450 \mathrm{~A}$ discharge nozzles of which distance is $2.8 \mathrm{~m}$ were added to the vessel along the starboard side near the stern at a depth of $\sim 2 \mathrm{~m}$ below the water level (Figure 9, Figure 10).

CFD analysis for the $\mathrm{pH}$ of discharge washwater has been performed to show that the $\mathrm{pH}$ of discharge washwater becomes 6.5 before $4.0 \mathrm{~m}$ from every discharge nozzle.

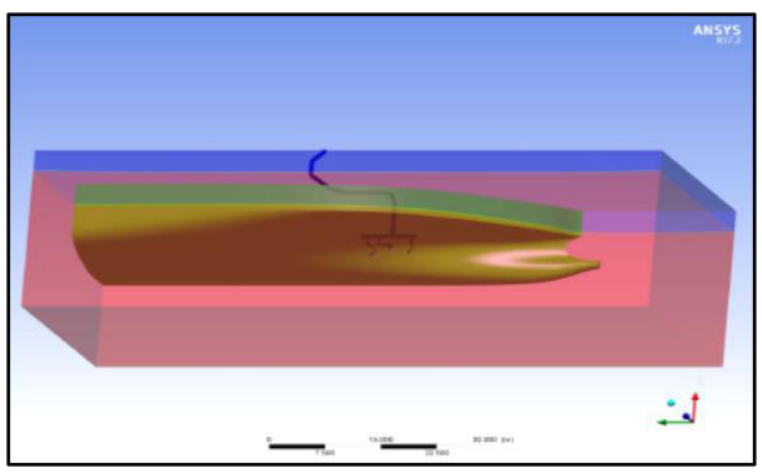

Fig. 9. Hull and discharge nozzles from CAD. 


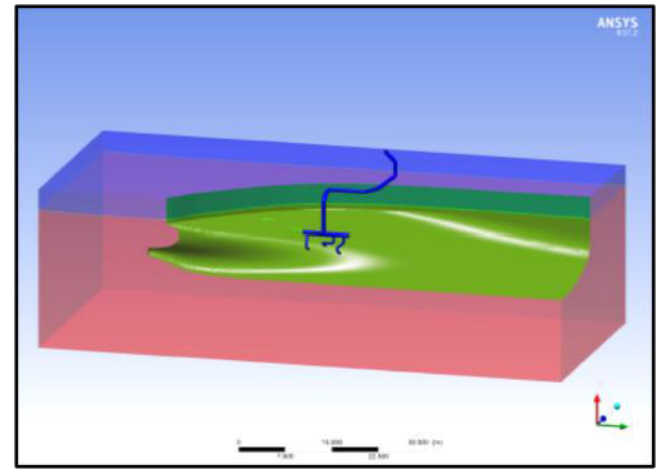

Fig. 10. Hull and discharge nozzles for CFD

\subsubsection{CFD Methodology}

The seawater flow induced by discharge washwater creates flow streamline in air phase which is in contact with the sea phase (Figure 11, Figure 12).

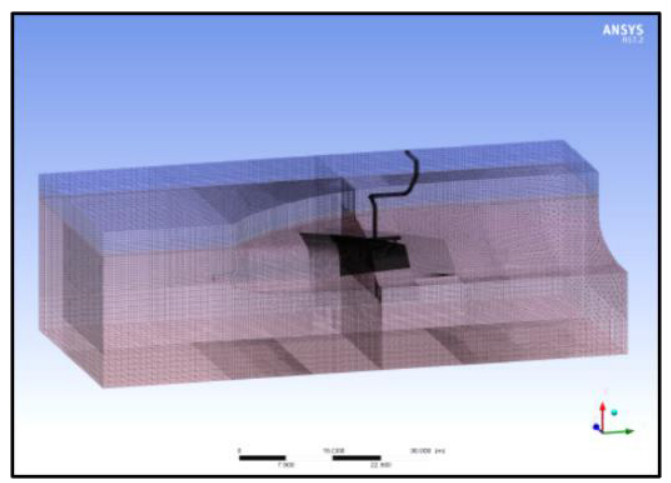

Fig. 11. Mesh structure for the CFD simulation.

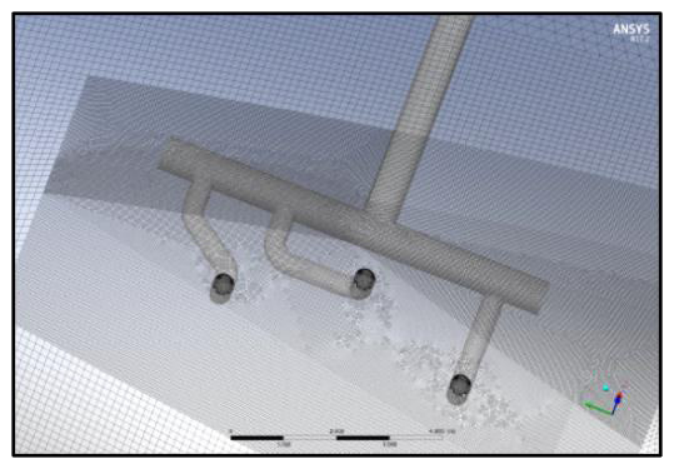

Fig. 12. Mesh structure for the pipes CFD simulation. 


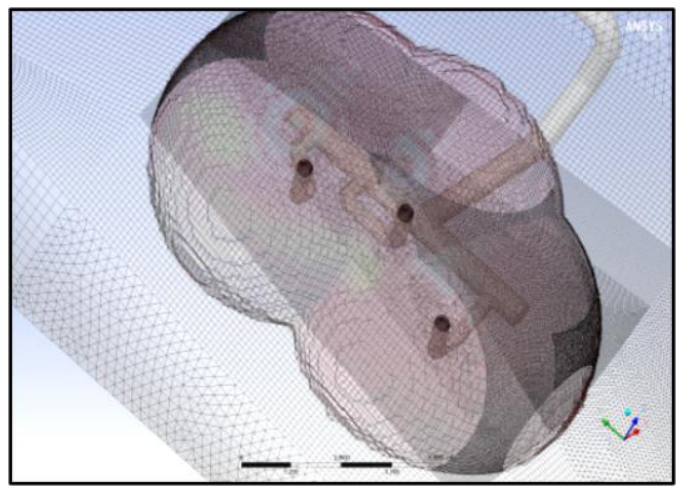

Fig. 13. Mesh structure for near the discharge nozzles.

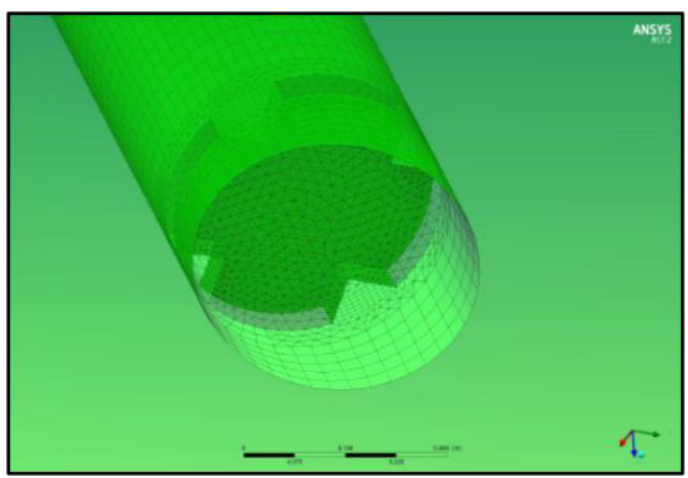

Fig. 14. Mesh structure forintire discharge nozzles.

For the current analysis, a mesh system was used which consists of 8,618,388 computational cells. The number of mesh for sectional area of discharge washwater was 100. The cell size at discharge outlet is $2 \mathrm{~cm}$ to be fine enough in discharge area and in the dilution area (at least $4 \mathrm{~m}$ away from the discharge point) and the cell size at $4 \mathrm{~m}$ distance from discharge points is $3 \sim 6 \mathrm{~cm}$. The current analysis utilized the steady state, multiphase, $3 \mathrm{D}$, turbulent, fluid solvers. The turbulence model used was the $\mathrm{k}-\varepsilon$ model. The size of computational domain was $49 \mathrm{~m}$ width, $25 \mathrm{~m}$ depth and $21 \mathrm{~m}$ height.

\subsubsection{Boundary Conditions}

For this CFD simulation, seawater phase and air phase are considered at the same time, multiphase flow, sea and air flow, analysis model was applied. The surface energy at the interface between air and seawater was given $0.017 \mathrm{~N} / \mathrm{m}$. The gravitational acceleration on seawater and air is $9.81 \mathrm{~m} / \mathrm{s}^{2}$. All the boundaries of sea except the face of discharge nozzle location is open sea. The lower part of computational domain, the ocean, is treated as a wall with a shear zero condition having $25^{0}$ temperature condition. Wall with two discharge nozzles installation by simplifying the hull were subjected to no slip wall condition and temperature of the wall was $25^{0} \mathrm{C}$. The three sides of the computational domain were covered by opening boundary conditions in Ansys, with temperatures of $25^{\circ} \mathrm{C}$ and $\mathrm{pH}$ of 
8.2. The upper surface and lateral surface of the air domain adjacent to the sea domain was treated as wall of $25^{\circ} \mathrm{C}$. The gas entrained in the washwater was taken to be air at standard temperature. The air affects the variations in turbulence in the flow to the gas phase were incorporated in the flow model because of bubble break-up, bubble coalescence. All simulations were carried out with $10 \%$ air contained washwater, with homogenous bubble sizes of $2 \mathrm{~mm}$ diameter.

\section{Results}

EGCSA PPR2 (Exhaust Gas Cleaning System - Pollution Prevention and Response) was used to predict the change in $\mathrm{pH}$ of the emission water after it was discharged into the sea. Depending on the predicted dilution rate in EGCSA PPR2, the $\mathrm{pH}$ of the emission water can be checked and this analysis shows that the emission water rises to $\mathrm{pH} 6.5$ before reaching $4.0 \mathrm{~m}$ point at the discharge point.

This method tracks the $\mathrm{pH}$ value of the fluid exiting the discharge nozzle and uses convection, turbulence, and diffusion to predict the $\mathrm{pH}$ value downstream within the entire flow domain based on the boundary conditions provided. The method is passive in that no chemical reactions are considered or modeled.

In this analysis, the $\mathrm{pH}$ is predicted by comparing the titration curve and seawater with the concentration result of the discharge washwater predicted by CFD analysis. The typical $\mathrm{pH}$ estimation results for discharge washwater stream according to the degree of dilution by seawater are shown in table below (Table 2)[5].

Table 2. $\mathrm{pH}$ correlation table according to dilution ratio.

\begin{tabular}{|c|c|c|}
\hline \multicolumn{2}{|c|}{ Volume fraction } & $\mathrm{pH}$ \\
\hline Discharge water & Seawater & \\
\hline 1 & 0 & 6.5 \\
\hline 0.65 & 0.35 & 6.13 \\
\hline 0.39 & 0.61 & 5.74 \\
\hline 0.28 & 0.72 & 5.13 \\
\hline 0.21 & 0.79 & 3.93 \\
\hline 0.19 & 0.81 & 3.52 \\
\hline 0.17 & 0.83 & 3.31 \\
\hline 0.16 & 0.84 & 3.23 \\
\hline
\end{tabular}

\subsection{Comparison between the manufacturer system specification and the CFD modeling results}

Eulerian multiphase computer simulation of CFD was carried out for max load case, 2.200 $\mathrm{m}^{3} / \mathrm{h}$. To check the boundary of $\mathrm{pH} 6.5$, surface contour of volume fraction, 0.16 is confirmed and shown in the CFD results.

\subsubsection{Max.Flow}

The contour value is calculated automatically by CFX. It demonstrates that plume of discharged water dilutes to a $\mathrm{pH} 6.528$ when $\mathrm{pH}$ at discharge point is 3.2 (Figure 15, figure 16, Figure 17). It satisfied the IMO regulations \& MEPC 259 (68) 10.1.2.1.2 (Marine Environment Protection Committee Resolution). 


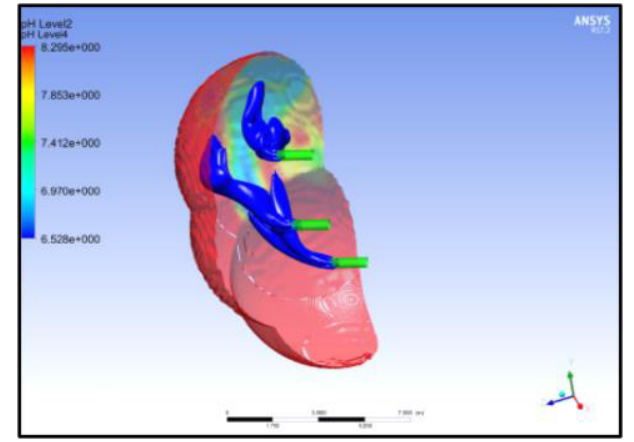

Fig. 15. pH 6.5 plume of discharge washwater and $4.0 \mathrm{~m}$ sphere with $2.200 \mathrm{~m} 3 / \mathrm{h}$ (Max. Flow).

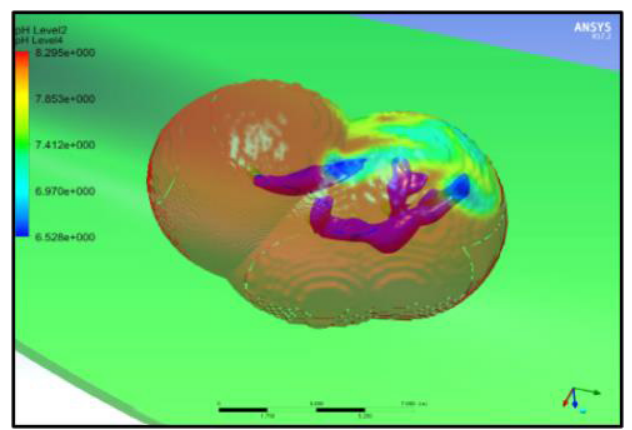

Fig. 16. pH 6.5 contour of discharge washwater stream and $4.0 \mathrm{~m}$ sphere with $2.200 \mathrm{~m} 3 / \mathrm{h}$ (Max. Flow).

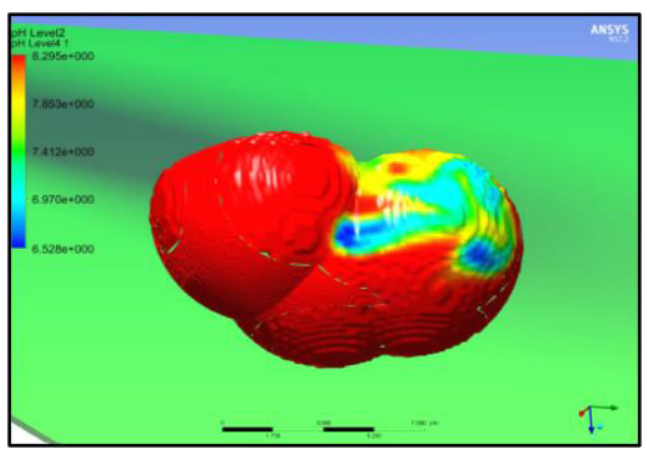

Fig. 17. Contour from front-view with $2.200 \mathrm{~m}^{3} / \mathrm{h}$ (Max. Flow).

\subsubsection{Min.Flow}

The plume of discharged water dilutes to a $\mathrm{pH} 6.594$ when $\mathrm{pH}$ at discharge point is 3.2 (Figure 18, Figure 19, Figure 20). It is satisfied with IMO regulations \& MEPC 259(68) 10.1.2.1.2 (Marine Environment Protection Committee Resolution). 


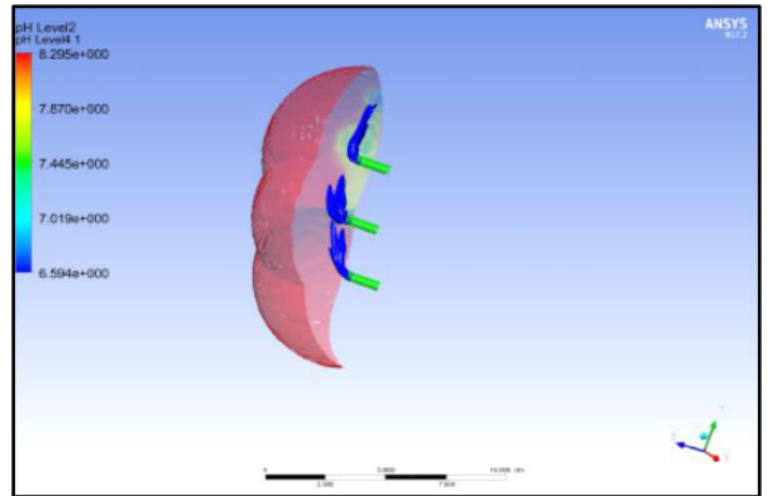

Fig. 18. pH 6.5 plume of discharge washwater and $4.0 \mathrm{~m}$ sphere with $990 \mathrm{~m}^{3} / \mathrm{h}$ (Min. Flow).

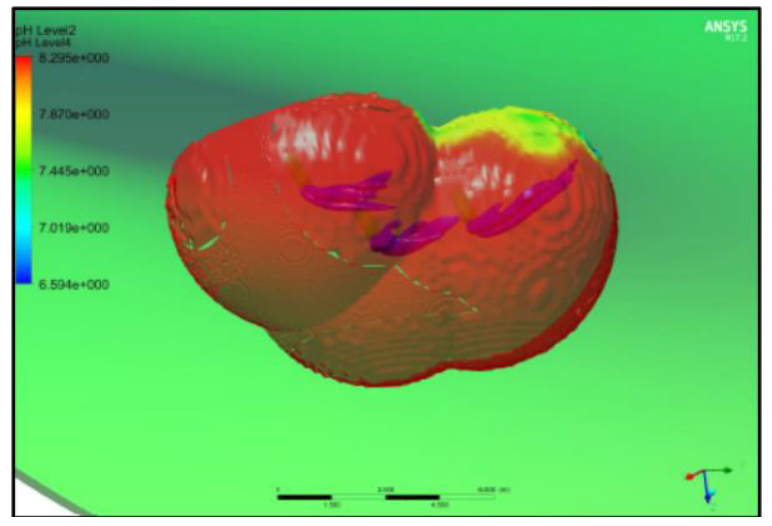

Fig. 19. Contour from front-view with $990 \mathrm{~m} 3$ /h (Min. Flow).

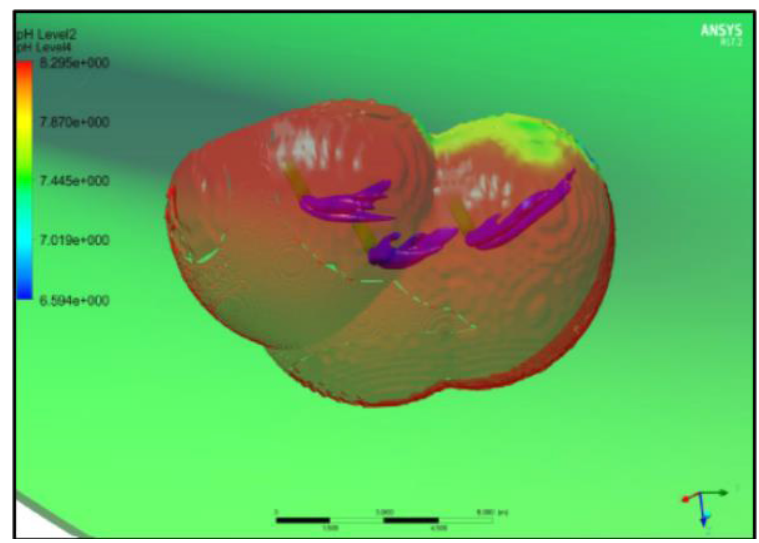

Fig. 20. Contour from side-view with $990 \mathrm{~m}^{3} / \mathrm{h}$ (Min. Flow).

\subsubsection{Comparison between IMO PPR 2/2/3 and our results}

Area of 1 hole in discharge nozzle with diffuser is $0.0075 \mathrm{~m}^{2}$. In this case, $\mathrm{pH}$ is calculated to 3.01 according to IMO PPR 2/2/3.

The results extracted from Ansys Fluent software are reliable are similar with IMO PPR 2/2/3 (Table 3). 
Table 3. Comparison between IMO PPR 2/2/3 results and the results from Ansys Fluent software

\begin{tabular}{|c|c|c|c|}
\hline Method by PPR2 & Dilution Factor & $\mathrm{SO}_{2}-$ Discharge & $\begin{array}{c}\mathrm{pH} \text { Limit to recover } \\
\mathrm{pH} 6.5\end{array}$ \\
\hline Source 1 & 7.76 & 3.60 & 3.01 \\
\hline Source 2 & 9.31 & 4.32 & 2.84 \\
\hline Source 3 & 8.23 & 3.82 & 2.96 \\
\hline Source 3 Min & 8.37 & 3.89 & 2.94 \\
\hline Source 3 Max 8 & 8.08 & 3.75 & 2.98 \\
\hline Our Result & 6.23 & 2.89 & 3.20 \\
\hline
\end{tabular}

\section{Conclusions}

From the $\mathrm{pH}$ prediction of discharged/diluted water and dilution modeling, we have concluded that:

- To reach the $\mathrm{pH}$ of 6.5 at $4 \mathrm{~m}$ from discharge, discharge washwater should be mixed to seawater with dilution ratio 1.6: 8.4 when the $\mathrm{pH}$ of discharge washwater is 3.2 on max load case of EGCS;

- In maximum load case, CFD simulation shows that the plume for 1.6: 8.4 dilution ratio is whining the range of $4 \mathrm{~m}$ from discharge;

- Discharge washwater with pH 3.2 or more confirms compliance to MARPOL regulations 14.1 and 14.4. on maximum load case;

- Discharge washwater is satisfied with a $\mathrm{pH}$ of no less than 6.5 at $4 \mathrm{~m}$.

\section{References}

1. M. V. Vasilescu, Ph. D. Thesis, Research on the design and operation of container vessels for improving energy efficiency, 7 (2020)

2. Hyundai Power System, Operation and maintenance manual. Project-Scrubber, 12 (2019)

3. Hyundai Power System, Operation and maintenance manual. Project-Scrubber, 14 (2019)

4. Hyundai Power System, SECP EGC System - SO $O_{x}$ Emissions Compliance Plan, Project - EGCS open for chtr., 4 (2019)

5. http://eng.hhi-power.com/business/scrubber/index.jsp.

6. Hyundai Power System, EGC System Record Book/Log, Project-EGCS open for cntr., 7 (2019)

\section{Acknowledgments}

Authors gratefully acknowledge to this material support path received under Project PN-IIIP1-1.2-PCCDI-2017-0404/ 31PCCDI / 2018, Holistic on the Impact of Renewable Energy Sources on Environment and Climate-HORESEC. 